\title{
Knowledge and management of fever in parents of children under 5 years of age at a children's hospital
}

\author{
Vanesa E. Castellano, M.D. ${ }^{a}$, Natalia Talamona, M.D. ${ }^{a}$, Norberto D. Giglio, M.D. ${ }^{a}$, \\ Liliana Sabbaj, M.D. ${ }^{b}$ and Ángela Gentile, M.D. ${ }^{a}$
}

a. Department of Health Protection and Promotion, Area of Epidemiology.

b. Outpatient Facilities of the Department of Pediatrics.

Hospital de Niños

Ricardo Gutiérrez,

Autonomous City

of Buenos Aires,

Argentina.

\section{E-mail adress:}

Vanesa E. Castellano,

M.D.:

vane0108@hotmail.com

\section{Funding:}

This study was funded by an unrestricted grant awarded by Sanofi Aventis, which was used in relation to the survey materials, and an educational grant awarded to Natalia

Talamona, M.D.

Conflict of interest:

The authors

V. Castellano, N. Giglio,

L. Sabbaj, and

Á. Gentile did not receive any fee for this project.

V. Castellano, N. Giglio and Á. Gentile

were lecturers in a

conference sponsored

by Sanofi Aventis in the context of a National

Conference of the

Argentine Society of

Pediatrics.

Received: 4-24-2019

Accepted: 10-3-2019

\section{ABSTRACT}

Introduction. In pediatrics, fever is a common reason for consultation. The objective was to assess parental knowledge, behaviors, and fears in the management of fever in their children.

Materials and methods. Observational, analytical, cross-sectional study. In 2018, a survey was administered to the parents of children aged 6 months to 5 years who attended Hospital de Niños Ricardo Gutiérrez, in the Autonomous City of Buenos Aires. The association between sociodemographic outcome measures and knowledge, behaviors, and fears in cases of fever was analyzed.

Results. A total of 201 surveys were completed: $56.7 \%$ of parents considered that fever was bad for health; $37 \%$ defined fever between $37^{\circ} \mathrm{C}$ and $37.5^{\circ} \mathrm{C}$, and $59 \%$, between $38^{\circ} \mathrm{C}$ and $38.5^{\circ} \mathrm{C}$. The mean temperature considered severe was $39.2{ }^{\circ} \mathrm{C}$ (standard deviation: 0.69). Physical methods were used by $93 \%$ of caregivers; $97 \%$ administered antipyretic agents, and $14.5 \%$ used alternating agents. Fears of consequences included seizures in $82 \%$, dehydration in $41 \%$, brain damage in $18 \%$, and death in $12 \%$. Also, $86.5 \%$ woke up their children to give them an antipyretic agent. Among the higher maternal education level, fear of fever was lower (odds ratio: $0.5 ; 95 \%$ confidence interval: $0.28-0.91$ ).

Conclusions. One-third of survey respondents considered low body temperature values as fever. Fear of fever was high, and the level of maternal education may mitigate it.

Key words: fever, antipyretic agents, parents, knowledge, behavior, health practice, surveys and questionnaires.

http:/ / dx.doi.org/10.5546/ aap.2020.eng.89

Tocite:Castellano VE, Talamona N, Giglio ND, SabbajL, Gentile A. Knowledge and management of fever in parents of children under 5 years of age at a children's hospital. Arch Argent Pediatr 2020;118(2):89-94.

\section{INTRODUCTION}

Fever is one of the most common reasons for consultation in pediatric practice. It has been estimated that 20$40 \%$ of children see a physician due to a fever, which is more common in infants younger than 18 months old. ${ }^{1}$ Most fever episodes are caused by self-limited, benign, viral infections that do not require treatment; ${ }^{2}$ however, the diagnostic approach varies depending on the risk for age.

Parental knowledge and behaviors when dealing with fever have been a topic of interest because they may affect the care of a fevered child as well as their relation to the health care system. ${ }^{3,4}$ Multiple factors related to an unjustified fear of fever, defined as fever phobia, have been described in the bibliography and continue to date. 6,7 Cultural, educational, socioeconomic, and health care system factors have been associated with fear of fever and fever phobia., ${ }^{3,-11}$

Parents' anxiety due to fear of consequences may predispose them to an excessive use of antipyretic agents and antibiotics, as well as a disproportionate utilization of emergency services. ${ }^{2,9,12}$ In addition, the increased use of antipyretic agents ${ }^{6}$ may lead to higher dosing errors in certain populations. ${ }^{13,14}$

The objective of this study was to assess parental knowledge, behaviors, and fears in the management of fever in their children. These results will help to develop educational and care strategies.

\section{METHODOLOGY}

This was an observational, crosssectional, analytical study carried out between August and October 2018 
using a survey administered by health care staff. The parents or caregivers of healthy children between 6 months old and 5 years old who attended the outpatient offices of Hospital de Niños Ricardo Gutiérrez for a health checkup were included. Caregivers with difficulties to understand the survey were excluded.

Sociodemographic data (age, origin, socioeconomic level as per Graffar's modified method, ${ }^{15}$ and level of maternal education) and data related to knowledge, behaviors, and fears in the management of fever were collected. A risk behavior was defined as using a mercury thermometer to measure temperature, using a cloth with alcohol or giving the child a bath with cold water to lower the fever. Finally, parents were asked about their expectations in relation to the medical consultation.

Based on a questionnaire about fever, ${ }^{16}$ our version was adapted and new questions were introduced in relation to the study objectives. Then, a pilot test was done in 30 subjects to assess the questionnaire structure and readability. The questionnaire is shown in Annex 1.

A descriptive analysis was performed. Quantitative outcome measures were described as mean and median values, whereas categorical outcome measures, as percentages and their corresponding $95 \%$ confidence intervals (95\% CI). To establish if there was an association between sociodemographic outcome measures and behaviors in cases of fear of fever (believing that fever was bad for health), the odds ratio (OR) and its corresponding $95 \%$ CI were estimated.

The sample size was estimated based on the population in the study period, with a hypothetical frequency of $50 \%( \pm 5)$ believing that fever was harmful ${ }^{16}$ and a $95 \%$ confidence level. At least 197 surveys were required. Data were analyzed using the STATA software, version 13.

This study was approved by the Research and Teaching Committee and the Research Ethics Committee of Hospital de Niños Dr. Ricardo Gutiérrez and, in all cases, a written informed consent was obtained.

\section{RESULTS}

A total of 201 surveys were completed. All survey respondents were mothers; three parents refused to take the survey. No case was excluded. Sociodemographic outcome measures are described in Table 1.

TABLE 1: Sociodemographic outcome measures

\begin{tabular}{llr}
\hline $\mathbf{N}=2 \mathbf{2 0 1}$ caregivers & & $\mathbf{N}(\%)$ \\
\hline Maternal education & Incomplete primary education & $6(3 \%)$ \\
& Complete primary education & $24(12 \%)$ \\
& Incomplete secondary education & $48(24 \%)$ \\
& Complete secondary education & $84(42 \%)$ \\
& Incomplete university education & $16(8 \%)$ \\
Place of residence & Complete university education & $23(11.44 \%)$ \\
Nationality & CABA & $64(31.84 \%)$ \\
& Province of Buenos Aires & $137(68 \%)$ \\
& Argentinian & $116(57.71 \%)$ \\
& Paraguayan & $33(16.42 \%)$ \\
Bolivian & $25(12.4 \%)$ \\
Socioeconomic level & Peruvian & $16(7.96 \%)$ \\
Graffar's modified method) & Venezuelan & $5(2.5 \%)$ \\
& Colombian & $2(1 \%)$ \\
& Nigerian & $1(0.5 \%)$ \\
& Chilean & $1(0.5 \%)$ \\
& Cameroonian & $1(0.5 \%)$ \\
& Chinese & $1(0.5 \%)$
\end{tabular}

CABA: Autonomous City of Buenos Aires. 
Out of all survey respondents, $114(56.7 \%$; $95 \%$ CI: 49.8-63.4) indicated that they believed fever was bad for health. Figure 1 shows the proportion by level of maternal education. Table 2 describes the answers to the questionnaire in relation to knowledge of and behaviors toward fever. When asked if they had consulted a physician for the most recent fever episode, 146 parents (72.6 \%; $95 \%$ CI: 66.2-78.5) said yes.

The mean temperature parents considered severe was $39.2{ }^{\circ} \mathrm{C}$ (standard deviation [SD]: 0.69). The fears of parents in relation to fever consequences are described in Table 3.

A total of 197 parents $(98 \%$; $95 \%$ CI: 95.399.4) used antipyretic agents to manage fever. Table 4 shows the pattern of antipyretic agent distribution and the dose interval. Among the parents who used alternating antipyretic agents, $26(89.6 \%)$ stated that this had been an indication of their pediatrician.
Among assessed behaviors that may be related to the fear of fever, 174 caregivers $(86.5 \%$; $95 \%$ CI: 81.3-90.8) woke up their children at night to give them an antipyretic agent, and $69(43.9 \%$; $95 \%$ CI: 36.3-51.8) implemented co-sleeping when their children had a fever, except for those who practiced co-sleeping routinely $(n=44)$. In relation to survey respondents' expectations during the medical consultation, it was observed that 185 (92\%; $95 \%$ CI: 87.7-95.2) expected the pediatrician to do a physical examination; 21 (10.45\%; $95 \%$ CI: 6.7-15.2), to order tests; and $11(5.47 \% ; 95 \%$ CI: 5.5-9.3), to prescribe antibiotics.

Among studied associations, it was observed that a higher level of maternal education (complete secondary or higher education) was associated with a lower fear of fever (OR: 0.5; $95 \%$ CI: 0.28-0.91). Other outcome measures, such as number of children and parents' age and

TABLE 2. Knowledge of and behaviors toward fever

\begin{tabular}{|c|c|c|}
\hline $\mathrm{N}=201$ caregivers & & $\mathbf{N}(\%)$ \\
\hline Definition of fever (lowest threshold) & $\begin{array}{l}37-37.5^{\circ} \mathrm{C} \\
38-38.5^{\circ} \mathrm{C} \\
\geq 39{ }^{\circ} \mathrm{C}\end{array}$ & $\begin{array}{r}73 \text { (36 \%; } 95 \% \text { CI: } 29.9-43.1) \\
118 \text { (59\%; } 95 \% \text { CI: 51.8-65.4) } \\
10 \text { (5\%; } 95 \% \text { CI: } 2.6-8.7)\end{array}$ \\
\hline Method used to measure temperature & $\begin{array}{l}\text { Thermometer } \\
\text { Touch }\end{array}$ & $\begin{array}{r}195 \text { (97\%; } 95 \% \text { CI: 93.9-98.8) } \\
6 \text { (3\%; } 95 \% \text { CI: } 1.2-6.18)\end{array}$ \\
\hline Type of thermometer used & $\begin{array}{l}\text { Digital } \\
\text { Mercury }\end{array}$ & $\begin{array}{r}167(83 \% ; 95 \% \text { CI: } 77.4-87.8) \\
34 \text { (16.9\%; } 95 \% \text { CI: } 12.2-22.6)\end{array}$ \\
\hline Body site for temperature measurement & $\begin{array}{l}\text { Armpit } \\
\text { Ear }\end{array}$ & $\begin{array}{r}194 \text { (96.5 \%; } 95 \% \text { CI: 93.2-98.5) } \\
1 \text { (0.5 \%; } 95 \% \text { CI: 0.02-2.4) }\end{array}$ \\
\hline Initial behaviors in the case of fever* & $\begin{array}{l}\text { Remove clothes and offer liquids } \\
\text { Visit the ER immediately } \\
\text { Visit the pediatrician immediately } \\
\text { Wait and see }\end{array}$ & $\begin{array}{r}105 \text { (52\%; } 95 \% \text { CI: 45.3-59.1) } \\
88 \text { (43.8\%; } 95 \% \text { CI: 37-50.7) } \\
30 \text { (15\%; } 95 \% \text { CI: 10.5-20.4) } \\
81 \text { (40.3\%; } 95 \% \text { CI: 33.7-47.2) }\end{array}$ \\
\hline Waiting time until first consultation $(\mathrm{n}=81)$ & $\begin{array}{l}24 \text { hours } \\
48 \text { hours } \\
72 \text { hours }\end{array}$ & $\begin{array}{l}46 \text { (56.8 \%; } 95 \% \text { CI: } 45.9-67.2) \\
21(25.9 \% ; 95 \% \text { CI: } 17.3-36.3) \\
14(17.3 \% ; 95 \% \text { CI: } 10.2-26.7)\end{array}$ \\
\hline Use of physical methods* & $\begin{array}{l}\text { No } \\
\text { A cloth with water } \\
\text { A bath with lukewarm water } \\
\text { A bath with cold water } \\
\text { Alcohol }\end{array}$ & $\begin{array}{r}14 \text { (7 \%; } 95 \% \text { CI: 4-11.1) } \\
119(59.2 \% ; 95 \% \text { CI: 52.3-65.8) } \\
121(60.2 \% ; 95 \% \text { CI: } 53.3-66.8) \\
8(4 \% ; 95 \% \text { CI: } 1.9-7.4) \\
5(2.5 \% ; 95 \% \text { CI: } 0.9-5.4)\end{array}$ \\
\hline
\end{tabular}

* Multiple-choice question.

TABLE 3. Parental beliefs about the risks of fever

\begin{tabular}{|c|c|c|}
\hline $\mathrm{N}=201$ caregivers & & $\mathbf{N}(\%)$ \\
\hline \multirow[t]{4}{*}{ Fear of consequences* } & Seizures & 165 (82.1\%; $95 \%$ CI: 76.3-86.9) \\
\hline & Dehydration & $84(41.8 \%$; $95 \%$ CI: $35.1-48.7)$ \\
\hline & Brain damage & 36 (17.9\%; $95 \%$ CI: $13.1-23.7)$ \\
\hline & Death & $24(11.9 \%$; $95 \%$ CI: 8-17) \\
\hline
\end{tabular}

* Multiple-choice question. 
nationality, did not show statistically significant differences. No differences were observed either in relation to behaviors (alternating antipyretic agents, medical consultation, co-sleeping, waking up children) and their association with fear of fever.

\section{DISCUSSION}

In our study, the entire population corresponded to mothers, and $64 \%$ had completed secondary or higher education. Half of survey respondents were Argentinian, followed by other Latin American nationalities, making this a heterogeneous hospital population. It is worth noting that most of them had a high education level compared to their low socioeconomic level.

Although there is evidence about the beneficial effects of mild and moderate fever, ${ }^{17,18}$ in our series, more than half of survey respondents considered that fever was bad for health, which was consistent with the regional data obtained by Ugarte et al. ${ }^{19}$ Other studies have also shown similar data and have described, in addition, an association between the level of maternal education and fear of fever. ${ }^{16,20}$

Cohee et al., observed cultural differences regarding fear of fever among survey respondents. ${ }^{8}$ In our series, no difference was observed between Argentinian and foreigner survey respondents. Initial hypotheses proposed that an older parental age and a higher number of children may reduce fear of fever; however, no differences were observed when these outcome measures were analyzed. The lack of evidence for the studied associations may be due to the small sample size for such analysis.

FIGURE 1. Proportion of survey respondents who expressed fear of fever in their children, by level of education

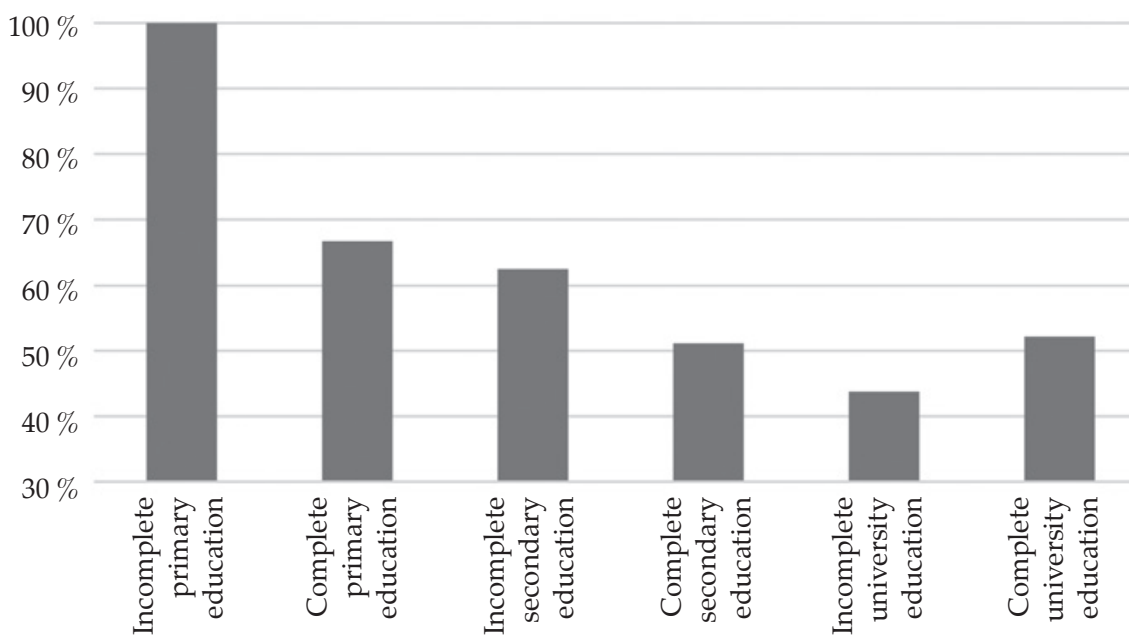

TABLE 4 . Use of antipyretic agents

\begin{tabular}{llr}
\hline $\mathbf{N}=1 \mathbf{1 9 7}$ caregivers & & $\mathbf{N}(\%)$ \\
\hline Antipyretic agents used* & Ibuprofen & $166(84.3 \% ; 95 \%$ CI: 78.7-88.9) \\
& Acetaminophen & $60(30.5 \% ; 95 \%$ CI: $24.3-37.1)$ \\
& Dipyrone & $23(11.6 \% ; 95 \%$ CI: $7.7-16.7)$ \\
Dosing & ASA & None \\
& $3-5 \mathrm{~h}$ & $9(4.6 \% ; 95 \%$ CI: $2.2-8.2)$ \\
Alternate use & $6 \mathrm{~h}$ & $101(51.2 \% ; 95 \%$ CI: $44.3-58.2)$ \\
& $8 \mathrm{~h}$ & $86(43.6 \% ; 95 \% \mathrm{CI}: 36.8-50.6)$ \\
& Never & $172(87.3 \% ; 95 \% \mathrm{CI}: 82.1-91.4)$ \\
& Sometimes & $24(12.2 \% ; 95 \% \mathrm{CI}: 8.1-17.3)$ \\
\hline
\end{tabular}

* Multiple-choice question.

ASA: acetylsalicylic acid. 
In relation to knowledge about fever management, one-third of survey respondents considered fever values that were below the definition of fever, similar to what has been described by other authors, ${ }^{3,21}$ and this may predispose to an inadequate antipyretic agent use and an overburden on the health care system. Among thermometer use, the digital type prevailed, as observed in other populations. $3,6,16,22$ It is worth noting that part of our sample used a mercury thermometer, and that there were differences compared to other studies, which showed a greater ${ }^{3}$ or smaller use. ${ }^{19}$ The preferred site to measure body temperature was the armpit in most cases, which is consistent with current recommendations. ${ }^{23-25}$

Although most fever episodes were benign and self-limited, the time between fever onset and the medical consultation was very short. ${ }^{26}$ In our series, $43 \%$ decided to visit the Emergency Department immediately. When asked about the most recent fever episode, approximately $70 \%$ had made a medical consultation, which reinforced the idea that fever was a reason for consultation at the health care system. Such situation poses a dual interpretation: on the one side, the need of parents to see a physician and rule out severe conditions and, on the other side, the importance of a rational resource use.

In the past 30 years, the recommendations on the use of physical methods to lower body temperature have been modified; ${ }^{9}$ there is currently no evidence of their benefit. ${ }^{24,27,28}$ However, consistent with other studies, most of our population uses physical methods to lower body temperature. ${ }^{3,8,19} \mathrm{~A}$ small percentage uses risk methods to lower fever, such as giving a bath with cold water or using a cloth with alcohol. Such risk practices were also described in a recent publication. $^{3}$

The beliefs regarding the potential secondary effects of fever are more or less consistent with those described in the bibliography, ${ }^{3,5,6,19}$ although it is worth noting that fear of seizures accounted for $82 \%$, which is higher than what has been reported in a meta-analysis of 40 studies included in the systematic review by Purssell et al. ${ }^{7}$

In our series, the dosage of antipyretic agents was adequate. Most parents did not use alternating antipyretic agents. In spite of the controversies about toxicity from alternating drugs, ${ }^{24,29-32}$ other studies have shown a greater use, $^{20,32}$ so it is believed that this finding may be related to the type of surveyed population, who received instructions at a teaching hospital.

Like in the study by Crocetti et al., ${ }^{6} 86 \%$ of parents woke up their children to give them antipyretic agents and less than half practiced cosleeping during the fever episode, which suggests that our population has a fear of fever, like in other regions. ${ }^{7}$

Our study has certain weaknesses because it was developed at a teaching hospital in the Autonomous City of Buenos Aires, so our findings may differ in other settings.

Being aware of parents' treatment expectations, fears, and perceptions during a medical consultation due to a fever episode is useful to prevent unnecessary procedures and tests. Future studies to better understand the influence of health education would be useful to mitigate parental anxiety in relation to fever.

\section{CONCLUSION}

Approximately one-third of survey respondents considered that fever was present in spite of low body temperature values, and more than half of them believed that fever was bad for health. The fear of consequences was high, although risk behaviors were low in our setting. The level of maternal education may mitigate the fear of fever.

\section{REFERENCES}

1. Hay AD, Heron J, Ness A; ALSPAC study team. The prevalence of symptoms and consultations in pre-school children in the Avon Longitudinal Study of Parents and Children(ALSPAC): A prospective cohort study. Fam Pract. 2005; 22(4):367-74.

2. Bruno M, Ellis A, Ferolla M, De Cristófano A, et al. Consenso para el uso adecuado de antibióticos en el niño menor de 36 meses con fiebre sin foco de infección evidente. Arch Argent Pediatr. 2017; 115(Supl 2):S27-37.

3. Pérez-Conesa MP, Sánchez Pina I, RidaoManonellas S, Tormo Esparza A, et al. Análisis de los cuidados y los conocimientos parentales sobre la fiebre en la infancia. Aten Prim (Barc). 2017; 49(8):484-91.

4. Blumenthal I. What parents think of fever. Fam Pract. 1998; 15(6):513-8.

5. Schmitt BD. Fever phobia: misconceptions of parents about fevers. Am J Dis Child. 1980; 134(2):176-81.

6. Crocetti M, Moghbeli N, Serwint J. Fever Phobia Revisited: Have Parental Misconceptions About Fever Changed in 20 Years? Pediatrics. 2001; 107(6):1241-6.

7. Purssell E, Collin J. Fever phobia: The impact of time and mortality: a systematic review and meta-analysis. Int J Nurs Stud. 2016; 56:81-9.

8. Cohee L, Crochetti M, SerwintJ, Sabath B, et al. Ethnic Differences in Parental Perceptions and Management of Childhood Fever. Clin Pediatr (Phila). 2010; 49(3):221-7.

9. Walsh A, Edwards H. Management of childhood fever by parents: literature review. J Adv Nurs. 2006; 54(2):217-27.

10. Rupe A, Ahlers-Schmidt CR, Wittler R. A comparison of perceptions of fever and fever phobia by ethnicity. Clin 
Pediatr (Phila). 2010; 49(2):172-6.

11. Taveras EM, Durousseau S, Flores G. Parents' beliefs and practices regarding childhood fever: a study of a multiethnic and socioeconomically diverse sample of parents. Pediatr Emerg Care. 2004; 20(9):579-87.

12. Li S, Lacher B, Crain E. Acetaminophen and ibuprofen dosing by parents. Pediatr Emerg Care. 2000; 16(6):394-7.

13. Yin HS, Mendelsohn A, Wolf M, Parker R, et al. Parents' medication administration errors: role of dosing instruments and health literacy. Arch Pediatr Adolesc Med. 2010; 164(2):181-6.

14. Charkaluk ML, Kalach N, ElKohen R, KrempO. Utilisation familiale de $1 \square$ ibuprofene chez $1 \square$ infantfébrile: uneétude prospective aux urgencesd $\square$ un hospital lillois. Arch Pediatr. 2005; 12(8):120914.

15. Méndez Castellano H, Méndez MC. Sociedad y Estratificación: Método Graffar-Méndez Castellano. Caracas: FUNDACREDESA; 1994.

16. García Puga JM, Callejas PozoJE, CastilloDíaz L, Hernández Morillas D, et al. Conocimientos y actuación de los padres sobre la fiebre. RevPediatr Aten Primaria. 2011; 13(51):36779 .

17. Blatteis CM. Fever: pathological or physiological, injurious or beneficial? J Therm Biol. 2003; 28(1):1-13.

18. Roth J, Rummel C, Harré E, Voss T, et al. Is interleukin-6 the necessary pyrogenic cytokine? J Therm Biol. 2004; 29(78):383-9.

19. Ugarte EM, Orue C, Samudio-D GC, Weber E. Los padres y la fiebre: ¿Qué creen y hacen? Pediatr (Asunción). 2009; 36(3):201-5.

20. Carabaño Aguado I, Llorente Otones L, Martínez Antón A, Ruiz Contreras J. Hábitos de consumo y preferencia de antitérmicos en pacientes de nuestro medio. Pediatr Aten Prim. 2006; 8(29):39-49.

21. Teuten P, Paul SP, Heaton PA. Management of acute childhood fevers. J Fam Health. 2015; 25(4):26-9.

22. Chiappini E, Principi N, Longhi R, Tovo P, et al.
Management of fever in children: summary of the Italian Pediatric Society guidelines. Clin Ther. 2009;31(8):1826-43.

23. National Institute for Health and Care Excellence (NICE). Fever in under 5s: assessment and initial management. May 2013. [Accessed on: March 1, ${ }^{\text {st }}$ 2019]. Available at: https:/ / www.nice.org.uk/guidance/cg160.

24. Clarke P. Evidence-based management of childhood fever: What pediatric nurses need to know. J Pediatr Nurs. 2014; 29(4):372-5.

25. Mintegi Raso S, González Balenciaga M, Pérez Fernández A, Pijoán Zubizarreta JI, et al. Lactantes de 3-24 meses con fiebre sin foco en urgencias: características, tratamiento y evolución posterior. An Pediatr (Barc). 2005; 62(6):522-8.

26. Castellarnau-Figueras E. Avances en terapéutica. Antitérmicosen pediatría. An Pediatr Contin. 2006; 4(2):11524.

27. Melamud A, Suwezda A, Matamoros, Ringuelet L. Indicación de antitérmicos por médicos pediatras. Internet como modalidad de recolección de datos. Arch Argent Pediatr. 2008; 106(5):404-8.

28. Buñuel Álvarez JC, Olivares Grohnertb M. En niños de 6 a 36 meses controlados en atención primaria, la alternancia de paracetamol e ibuprofeno parece más eficaz que la monoterapia para disminuir la fiebre, sin poderse determinar la seguridad de esta pauta. Rev Pediatr Aten Primaria. 2007; 9(Supl 1):S103-7.

29. Moreno-Pérez D, Chaffanel Peláez M. Antitérmicos, padres y pediatras. ¿Tenemos conclusiones para todos ellos? Evid Pediatr. 2006; 2(2):16.

30. Díez Domingo J, Ballester Sanz A. Utilización secuencial de antitérmicos. ¿Basado en la evidencia o la costumbre? An Esp Pediatr. 1999; 50(1):105-6.

31. Wong T, Stang A, Ganshorn H, Hartling L, et al. Combined and alternating paracetamol and ibuprofen therapy for febrile. Evid Based Child Health. 2014; 9(3):675-729.

32. Carabaño Aguado I, Llorente Otones L. Fiebre y niños: puesta al día. Acta Pediatr Esp. 2008; 66(2):57-66. 


\section{Annex 1. Survey}

1. Age of father/mother/legal guardian: years old.

2. Level of maternal education:

1. Incomplete primary education/2. Complete primary education/3. Incomplete secondary education/ 4. Complete secondary education./5. Incomplete tertiary or university education/ 6. Complete tertiary or university education.

3. Number of children:

4. Age of child(ren):
1. (y.o./m.o.).
2. (y.o./m.o.).
4. (y.o./m.o.).
5. (y.o./m.o.).

3. (y.o./m.o.).

5. Place of residence:
1. Aut. City of Buenos Aires. 2. Province of Buenos Aires.
3. Other.

6. Nationality:
1. Argentine.
2. Other:

7. Socioeconomic level:

1. I. 2. II. 3. III. 4. IV. 5. V.

8. Do you think fever is bad for health?

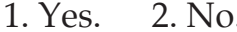
3. I do not know.

9. Do you use a thermometer to measure body temperature?

1. Yes. 2. No.

10.If you use a thermometer, what type is it?
1. Ear.
2. Forehead.
3. Digital.
4. Mercury.*
5. Other.

11.If you use a thermometer, in what part of the body do you take the temperature?
1. Armpit. 2. Rectum.
3. Forehead.
4. Mouth.
5. Ear.

12.If you do not use a thermometer, what method do you use?

13. What temperature do you consider fever?
1. 37.
2. 37.5.
3. 38 .
4. 38.5.
5. $>39$.

14. What fever value do you consider severe?

15.Do you think fever may cause any of the following?
1. Brain damage.
2. Seizures.
3. Death.

4. Dehydration.

5. None.

16.What is the first thing you do when your child has a fever?

\begin{tabular}{l|l}
\hline I remove their clothes and give them liquids. & \\
\hline I give them anti-fever agents. & \\
\hline I take them to their pediatrician. & \\
\hline I take them to the Emergency Department. & \\
\hline I wait until the fever goes down on its own (if this is the case, how long & \\
do you wait before seeing a physician?). &
\end{tabular}

Other:

17.Do you use any of the following to lower the fever? You can select more than one.
1. A cloth with alcohol.*
2. A cloth with lukewarm water.
3. A shower or bath with lukewarm water.

4. A bath with cold water.* 5. Other:

6. No.

18. Did you see a doctor during the most recent fever episode?

1. Yes. 2. No.

19. Do you use any drug to lower the fever?

1. Yes. 2. No. 
20.Which drug(s) do you usually use?

1. Acetaminophen. 2. Ibuprofen.

3. Dipyrone. 4. Other:

21. How often do you give it to your child?

Every h.

22.Do you alternate between several anti-fever drugs?

$\begin{array}{ll}\text { 1. Sometimes. } & \text { 2. Never. Always. }\end{array}$

23.If you do so, who gave you the indication?

1. Family / friends. 2. Pharmacist. 3. Pediatrician. 4. Label.

24.Do you wake up your child during the night to give them the anti-fever drug?

1. Yes. 2. No.

25.When your child has a fever, do you take them to bed with you?

1. Yes. 2. No. 3. They always sleep with me.

26. When you see a physician due to a fever episode, what do you expect during the visit?

1. An indication for anti-fever agents.

2. An indication for antibiotics.

3. A physical examination. 4. Tests.

* Please explain this is risky or dangerous. 